\title{
Evaluation of Essential Oil of Fennel and Garlic Separately or Combined with Bacillus licheniformis on the Growth, Feeding Behaviour, Hemato-biochemical Indices of Oreochromis niloticus (L.) Fry
}

\section{Mohamed S Hassaan ${ }^{1 *}$ and Magdy A Soltan ${ }^{2}$}

${ }^{1}$ Fish Nutrition Research Laboratory, National Institute of Oceanography and Fisheries (NIOF), Egypt

${ }^{2}$ Animal Production Department, Faculty of Agriculture, Benha University, Egypt

\begin{abstract}
A total of six treatments, i.e., negative control group (D1), B. licheniformis $7 \times 10^{7} \mathrm{CFU} \mathrm{g}^{-1}$ diet (D2); $1 \mathrm{ml}$ essential fennel oil (EFO) $\mathrm{kg}^{-1}$ diet (D3); $1 \mathrm{ml}$ essential garlic oil (EGO) kg-1 diet (D4); B. licheniformis $7 \times 10^{7} \mathrm{CFU} \mathrm{g}^{-1}+1 \mathrm{ml}$

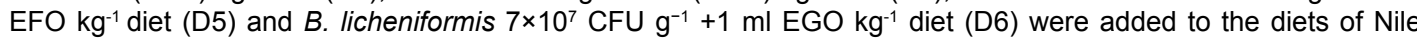
tilapia, Oreochromis niloticus to investigate the effects of the respective treatments on the growth, feeding behaviour, hematological and biochemical indices. Fish $(1.88 \pm 0.12 \mathrm{~g})$ were distributed at a rate of 20 fish per 100 - $\mathrm{L}$ aquarium and three aquaria have been assigned for each treatment. At the end of the experiment (84-day), results indicated that the highest survival, weight gain and specific growth rate were recorded by fish fed D5 and D6 being statistically different $(P<0.05)$ from other treatment groups. Whereas, the best feed conversion ratio and protein efficiency ratio were observed in D3, D4, D5 and D6 compared with other treatment groups. Fish feed D6 were higher in mouth wrestling and chasing behavior. Fish fed D5 and D6 significantly higher $(P<0.05)$ hematocrit and hemoglobin values also, was effectively enhanced aspartate aminotransferase, alanine aminotransferase, total protein and globulin in comparison to the other treatments. No significant differences were found in the chemical composition of whole body of fish fed different tested diets.
\end{abstract}

Keywords: Essential oil; Fennel; Garlic; Growth; Feeding behaviour; Hemato-biochemical; Tilapia

\section{Introduction}

Improving the bio-economic efficiency of aquaculture is dependent on advances in biology, nutrition and environmental management of the production cycle. Antimicrobials and other veterinary drugs are administered regularly as additives in fish food, are used as therapeutics or growth promoters [1]. Nevertheless, the use of veterinary drugs is becoming more restricted since they present numerous side-effects for the environment and health safety [2]. Use of antibacterial agents in aquaculture should be avoided as it leads to proliferation of resistant and creates a negative image for aquaculture industry. Use of essential oil extracted from herbs medicine, could be a valuable alternative instead of antibiotics because there are fewer chances for the development of resistant strains [3].

There are many aromatic plants such as oregano, rosemary, sage, peppermint, thymus, fennel and garlic in worldwide, especially in the Mediterranean area [4]. The extracted essential oil from aromatic plants are usually used for antioxidant [5], digestive stimulant [6].

Fennel, Foeniculum vulgare is a biennial medicinal plant belonging to the family Apiaceae (Umbelliferae). Essential oils of fennel have hepatoprotective effects [7], as well as anti-inflammatory, and antioxidant activities [8]. Many phytochemical studies have been conducted to study the chemical composition of the essential oil of fennel from different origins and have shown that the major components are phenylpropanoid derivatives and monoterpenoids [9].

Allium is the largest and most important genus of the Alliaceae family and comprises 450 species, which were widely distributed in the northern hemisphere. Among them, garlic (Allium sativum L.), is a well-known species being used in traditional medicine and food in many countries [10]. Garlic and its constituents have antimicrobial activity. It was showed that the antibacterial activity of garlic resulted from thio sulfinates, especially allicin, which is responsible for the antimicrobial activity, as well as its flavor and aroma [11]. Five types of garlic preparations are currently available on the market: garlic essential oils, garlic oil macerate, garlic powder, aged garlic extract and fresh garlic [12]. Among them, the antimicrobial activity of garlic oil is 200 times greater than garlic powder and 900 times the strength of fresh garlic [12].

Previous studies revealed that herbs medicine and essential extracted oil from herbs can be successfully used in fish nutrition such as Carum carvi seeds [13], Foeniculum vulgare seeds [14], Cuminum cyminum powder [15], ground garlic, Allium sativum [16,17], oil of oregano, Origanum heracleoticum [18,19], oil of thyme and fennel [20]. Furthermore, some aromatic plants and their extracts have been reported to stimulate the growth of certain bacteria where used a prebiotic, but these studies are scarce [21]. As aforementioned, many authors have attempted to examine various essential oil components from herbal plants, but information regarding fry culture, especially the effects of essential oil of fennel and garlic supplements and their combined with probiotics on fish performance and hematobiochemical blood parameters, is little. Therefore, the present study was designed to investigate the effect of fennel oil, garlic oil and Bacillus licheniformis alone and combined as dietary feed additives on growth

*Corresponding author: Mohamed S Hassaan, Fish Nutrition Research Laboratory, National Institute of Oceanography and Fisheries (NIOF), Egypt, Tel: +201229490092 Fax: +20 227943226; E-mail: Mohamed_shaban@yahoo.com

Received February 17, 2016; Accepted March 18, 2016; Published March 20 2016

Citation: Hassaan MS, Soltan MA (2016) Evaluation of Essential Oil of Fennel and Garlic Separately or Combined with Bacillus licheniformis on the Growth, Feeding Behaviour, Hemato-biochemical Indices of Oreochromis niloticus (L.) Fry. J Aquac Res Development. 7: 422. doi:10.4172/2155-9546.1000422

Copyright: (C) 2016 Hassaan MS, et al. This is an open-access article distributed under the terms of the Creative Commons Attribution License, which permits unrestricted use, distribution, and reproduction in any medium, provided the original author and source are credited. 
Citation: Hassaan MS, Soltan MA (2016) Evaluation of Essential Oil of Fennel and Garlic Separately or Combined with Bacillus licheniformis on the Growth, Feeding Behaviour, Hemato-biochemical Indices of Oreochromis niloticus (L.) Fry. J Aquac Res Development. 7: 422. doi:10.4172/2155-9546.1000422

Page 2 of 8

performance, feed utilization, hematological and biochemical blood parameters of Nile tilapia, O. niloticus fry.

\section{Materials and Methods}

\section{Fish, facility and feeding trial}

The feeding trial was performed at an indoor installation of the Aquaculture Laboratory, faculty of agriculture Benha University. Nile tilapia, O. niloticus fries were obtained from fish hatchery of central laboratory for aquaculture research, Abbassa, Abou-Hammad Sharkia, Egypt. Fry were acclimated for two weeks to the experimental conditions in a fiberglass tanks. During this period fish fed daily on the commercial diet to be adapted to pelleted feeds. At the beginning of the experiment, 18 (100-L) glass aquaria were stocked with 20 fish with an initial average weight $(1.88 \pm 0.12 \mathrm{~g})$. Each aquarium was supplied with compressed air via air-stones from air pumps. Overhead fluorescent illuminating was set at 14:10 (light:dark). All fish were fed, initially, at a rate of $6 \%$ of total body weight daily for the first 6-week and then decreased to $4 \%$ of total body weight daily for the remaining 12 -week [22]. The fish were fed four times a day at 10:00, 12:00, 14:00, and 16:00, 6 days a week, for 84 days. All aquaria were siphoned twice a day to remove faecal materials then replaced by aerated fresh water. Total fish weight in each aquarium was determined every 2 weeks to check their growth and to adjust the feeding rate. Feeding was stopped $24 \mathrm{~h}$ before sampling. Water samples for chemical analysis were monitored weekly during the experimental period. Dissolved oxygen and temperature were measured on site with an YSI model 58 oxygen meter (Yellow Spring Instrument Co., Yellow Springs, OH, USA). Total ammonia was measured using DREL/2 HACH kits (HACH Co., Loveland, Co. USA). $\mathrm{pH}$ was measured using a $\mathrm{pH}$ meter (Digital Mini-pH Meter, model 55, Fisher Scientific, USA). During the period of the feeding trial, the water-quality parameters were averaged $( \pm S D)$ : Water temperature was $26.25 \pm 0.9^{\circ} \mathrm{C}$ : dissolved oxygen, $5.7 \pm 0.5 \mathrm{mg} \mathrm{L}^{-1}: \mathrm{pH} 8.33 \pm 0.4$ and total ammonia, $0.07 \pm 0.01 \mathrm{mg} \mathrm{L}^{-1}$. All tested water quality criteria were suitable and within the acceptable limits for rearing the Nile tilapia $O$. niloticus [23].

\section{Extraction of essential oils and analysis}

Fresh fennel seeds were dried at $35^{\circ} \mathrm{C}$ and crushed to fine powders using a grinder. Essential oil was obtained by hydrodistillation of the powdered dry seeds using a Clevenger-type apparatus. The essential fennel oil (EFO) was separated, dried over anhydrous sodium sulfate. However, extraction of the essential garlic oils (EGO) from fresh cloves of garlic was performed with a hydrodistiller after mashed. The hydrodistillation lasted 3 hours. Essential oil with an unpleasant strong odor was obtained and dried by adding anhydrous sodium sulfate, filter sterilized through a 0.22 -mmfilter. Essential fennel and garlic oil were stored in a dark glass bottle at $4^{\circ} \mathrm{C}$ until use. The analysis of EFO and EGO were analyzed using gas chromatography-mass spectrometry (GC-MS) to identify their chemical constituents according to Aazza and Douiri et al. [24,25], respectively.

\section{Preparation inoculum of (B. licheniformis)}

Strain of Bacillus licheniformis used was obtained from Microbiological Resources Center (MIRCEN), faculty of Agriculture, Ain Shams University, Egypt. Inoclum was prepared by adding 5 $\mathrm{g}$ lyophilized cells of $B$. licheniformis to $100 \mathrm{ml}$ of specific media which containing $5 \mathrm{~g} \mathrm{~L}^{-1}$ peptone, $3 \mathrm{~g} \mathrm{~L}^{-1}$ beef extract at $\mathrm{pH} 7.0$ then was incubation at $37^{\circ} \mathrm{C}$ for 24 hours. After this period, cells were centrifugation for $15 \mathrm{~min}(2000 \mathrm{~g})$ then washed with phosphate buffered saline (PBS) with $\mathrm{pH}$ 7.3. The washed cells was added dropwise into the ingredients of diet before to pellet [26] until to reach the level $7 \times$ $10^{7}\left(\mathrm{CFU} \mathrm{g}^{-1}\right)$ of $7 \times 10^{7}\left(\mathrm{CFU} \mathrm{g}^{-1}\right)$ of $B$. licheniformis. The control diet received the same volume PBS to maintain an equal volume of PBS in all experimental diets.

\section{Experimental diets}

The basal practical diet was formulated to contain approximately (35\% crude protein and $19.96 \mathrm{MJ} \mathrm{Kg}^{-1}$ gross energy) (Table 1). The basal practical diet was divided into six parts. The first part prepared without feed additives as control diet (D1). Other five parts prepared to contain B. licheniformis at level $7 \times 10^{7}$ colony forming unit (CFU g ${ }^{-1}$ diet) diet

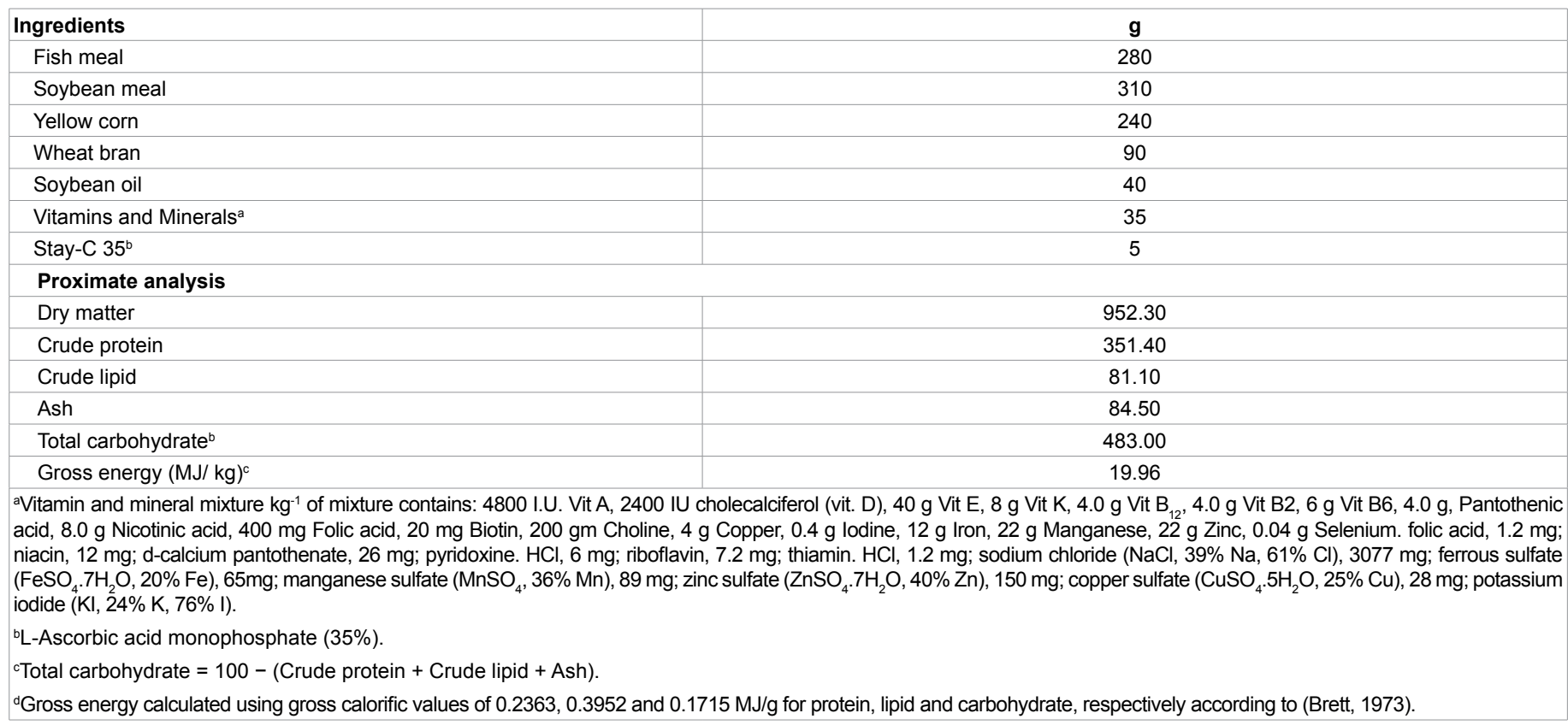

Table 1: Composition and proximate analysis of basal diet ( $\mathrm{g} / \mathrm{kg}$ diet). 
Citation: Hassaan MS, Soltan MA (2016) Evaluation of Essential Oil of Fennel and Garlic Separately or Combined with Bacillus licheniformis on the Growth, Feeding Behaviour, Hemato-biochemical Indices of Oreochromis niloticus (L.) Fry. J Aquac Res Development. 7: 422. doi:10.4172/2155-9546.1000422

(D2); $1 \mathrm{ml} \mathrm{EFO} \mathrm{kg-1}$ diet (D3); $1 \mathrm{ml} \mathrm{EGO} \mathrm{kg}{ }^{-1}$ diet (D4); $1 \mathrm{ml} \mathrm{EFO} \mathrm{+} \mathrm{B.}$ licheniformis $7 \times 10^{7} \mathrm{CFU} \mathrm{g}^{-1}$ diet (D5); $1 \mathrm{ml} \mathrm{EGO}+$ B. licheniformis $7 \times 10^{7}$ CFU g ${ }^{-1}$ diet (D6). Essential fennel and garlic oil were added separately to soybean oil. All dry ingredients were thoroughly mixed with soybean oil, and vitamins and minerals mixture using a homogenous mixture grinder, and then passing the mixed feed through a laboratory pellet mill (0.5-mm die) in National Institute of Oceanography and Fisheries, Cairo Governorate, Egypt (CMP California Pellet Mill, San Francisco, CA, USA).

\section{Feeding behaviour}

The observation of fish behaviour was conducted for 6 days from June $20^{\text {th }}$ until July $21^{\text {st }}$ to study the effects of experimental diets on fish behavior according to Hussein et al. [27] to study the effects of experimental diets on fish behaviour. The types of fish behavior included were mouth wrestling and chasing. Fish were fed manually their daily amount of the experimental diets four times a day at 10:00, 12:00, 14:00 and 16:00. Ten minutes after the third meal (14:00) all aquarium were observed individually and each aquarium was given 3 min to quantify the behavioural interactions (i.e., as mouth wrestling and chasing separately) between fish.

\section{Sample collection and analysis}

At the end of the trial a random sample of five individual fish were sampled from each aquarium, then oven-dried $105^{\circ} \mathrm{C}$ for $24 \mathrm{~h}$, ground, and stored at $-20^{\circ} \mathrm{C}$ for subsequent analysis. Proximate analysis was conducted on diets and fish samples. Dry matter, crude lipids, crude protein and ash content were determined by the standard [28]. Dry matter was determined after drying the samples in an oven $\left(105^{\circ} \mathrm{C}\right)$ for $3 \mathrm{~h}$. Crude protein was determined by micro-Kjeldhal method, $\mathrm{N} \times 6.25$ (using Kjeltech auto analyzer, Model 1030, Tecator, Höganäs, Sweden) [28] (method number 984.13), crude lipid by soxhlet extraction with diethyl ether $\left(40-60^{\circ} \mathrm{C}\right)$ [28] (method number 920.39) and ash by incineration at $550^{\circ} \mathrm{C}$ for $12 \mathrm{~h} \mathrm{[28]} \mathrm{(method} \mathrm{number} \mathrm{942.05).} \mathrm{Nitrogen-}$ free extract was computed by taking the sum of values for crude protein, crude lipid and ash then subtracting this sum from 100.

At the end of the feeding trial all fish were counted and weighed to calculate final body weight (FBW), weight gain (WG), specific growth rate (SGR\%), feed conversion ratio (FCR) and protein efficiency ratio (PER) using the following equations:

WG $(\mathrm{g} / \mathrm{fish})=\mathrm{FBW}-\mathrm{IBW} ; \mathrm{SGR} \%=[\ln \mathrm{FBW}-\ln \mathrm{IBW}] / \mathrm{t} \times 100$, where IBW is initial body weight $(\mathrm{g}) ; \ln =$ natural logarithmic; $\mathrm{t}=$ time in days. FCR = FI /WG, where FI is feed intake (g); PER=WG/protein intake $(\mathrm{g})$.

\section{Blood samples, hematological and biochemical blood param- eters}

At the end of experimental period, fish were fasted for $24 \mathrm{~h}$ prior to blood sampling. Fish were anaesthetized by tricaine methanesulfonate (MS222) at $250 \mathrm{mg} \mathrm{L}^{-1}$ in water. Blood was drawn near caudal peduncle from five fish from each treatment by a sterile syringe and transferred into a heparinized tube for hematological study. Blood was drawn from another five fish from each treatment kept outside without anticoagulant at room temperature $\left(26^{\circ} \mathrm{C}\right)$ for few minutes then centrifuged at 5,000 g for $15 \mathrm{~min}$ for separation of serum (collected serum was stored at $-20^{\circ} \mathrm{C}$ ) for biochemical study. Hematocrit (Hct) was determined as described by Reitman and Frankel [29]. $\mathrm{Hb}$ was determined by the hemoglobin kits which is a standardized procedure of the cyanomet hemoglobin method. RBCs were counted under the light microscope using a Neubauer haemocytometer after blood dilution with phosphate-buffered saline ( $\mathrm{pH}$ 7.2). Serum AST and ALT were determined colorimetrically using spectrophotometer using specific kits according to Reitman and Frankel [29]. Total serum protein and albumin and globulin were determined according to Doumas et al. [30].

\section{Statistical analysis}

Data were statistically analyzed by ANOVA using SAS ANOVA procedure (Statistical Analysis System 2004). The data were submitted to one ways classification variance analysis. Duncan's multiple range test was used to compare differences between treatment means when significant $F$ values were observed [31], at $(\mathrm{P}<0.05)$ level. All percentage data were arc-sin transformed prior to analysis [32], however data are presented untransformed to facilitate comparisons.

\section{Results}

\section{Essential oil composition}

The chromatographic analysis of hydro distilled oil revealed the presence of fifteen major compounds in EFO, representing 87.24\% of the total fennel oil. The compounds present in the fennel oil at concentrations higher than $2 \%$ are: estragole (47.94); limonene (20.64); fenchone (7.22); trans-Anethole (4.9) $\alpha$-Pinene (3.61) and eucalyptol (2.93). The chromatographic analysis of hydro distilled oil represented thirteen different compounds in EGO, representing $83.69 \%$ of the total garlic oil. The compounds present in the garlic oil at concentrations higher than $2 \%$ are: diallyl trisulfide (33.33\%); diallyl disulfide (20.61\%); methyl allyl trisulfide (14.11\%); propenyl dithiopropanoate (10.21\%); dimethyl trisulfide (3.20\%) and diallyl tetrasulfide (2.23\%). Diallyl tetrasulfide, which is generated from allicin is the main sulfurous constitute.

\section{Growth and feed utilization}

Survival at the end of the experiment was high (about 95\%) and the effect of dietary treatments was significant (Figure 1). No significant differences in survival of fish $(\mathrm{P}>0.05)$ were observed among fish groups fed diet (D2, D3 and D4). The survival of fish fed diet D6 (EGO $+B$. licheniformis) was significantly higher that of other treatments. The differences in body weight were first observed after the 4 weeks of the feeding and increased as the feeding period continued (Figure 2).

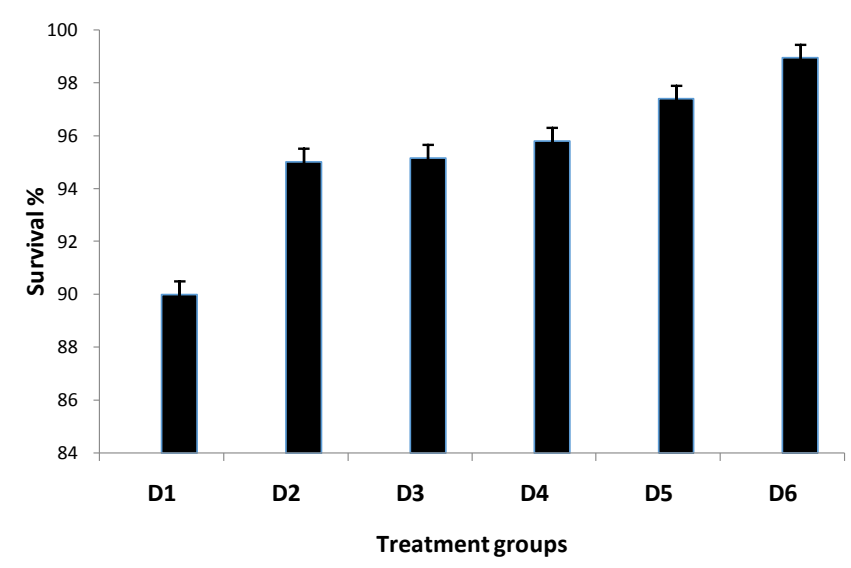

Figure 1: Survival of Nile tilapia fry fed diets containing $B$. licheniformis, fenne oil, garlic oiland their combinedfor 84 days. [D1= Control; D2 = B. licheniformis; D3 = Essential fennel oil (EFO); D4 = Essential garlic oil $(E G O) ; D 5=(E F O$ $+B$. licheniformis); $\mathrm{D} 6=(\mathrm{EGO}+\mathrm{B}$. licheniformis $)]$. 
Citation: Hassaan MS, Soltan MA (2016) Evaluation of Essential Oil of Fennel and Garlic Separately or Combined with Bacillus licheniformis on the Growth, Feeding Behaviour, Hemato-biochemical Indices of Oreochromis niloticus (L.) Fry. J Aquac Res Development. 7: 422. doi:10.4172/2155-9546.1000422

Moreover, a significant reduction in the final body weight of fish control was observed compared with fish fed other diets. Results of growth and feed utilization are presented in (Table 2) and indicated that the highest weight gain (WG) and specific growth rate (SGR) were recorded by fish fed D5 (EFO + B. licheniformis) and D6 (EGO + B. licheniformis). Furthermore, no significant differences were found in WG and SGR among D2 (B. licheniformis), D3 (EFO) and D4 (EGO). The highest FI was observed in fish fed D4 (EGO), D5 (EFO + B. licheniformis) and D6 $(\mathrm{EGO}+\mathrm{B}$. licheniformis). While, the best FCR and PER were observed in D3 (EFO), D4 (EGO), D5 (EFO + B. licheniformis) and D6 (EGO + B. licheniformis) in comparison to the other treatments groups.

\section{Feeding behavior}

The behavioural observation were recorded at week 7 (Figure 3) and the results showed significant differences among all treatments in terms of mouth wrestling and chasing behaviour. It showed that mouth wrestling and chasing behaviour were higher in fish feed D6 (EGO + B. licheniformis) resulting in more aggressive for pellets feed than all treatments diets. The opposite trend were observed in D1 (control diet).

\section{Hematological analysis and biochemical blood}

The changes in hematological parameters of Nile tilapia fed treated diets are presented in Tables 3 and 4. The highest hematocrit (Hct), hemoglobin ( $\mathrm{Hb})$ and red blood cells (RBCs) values were

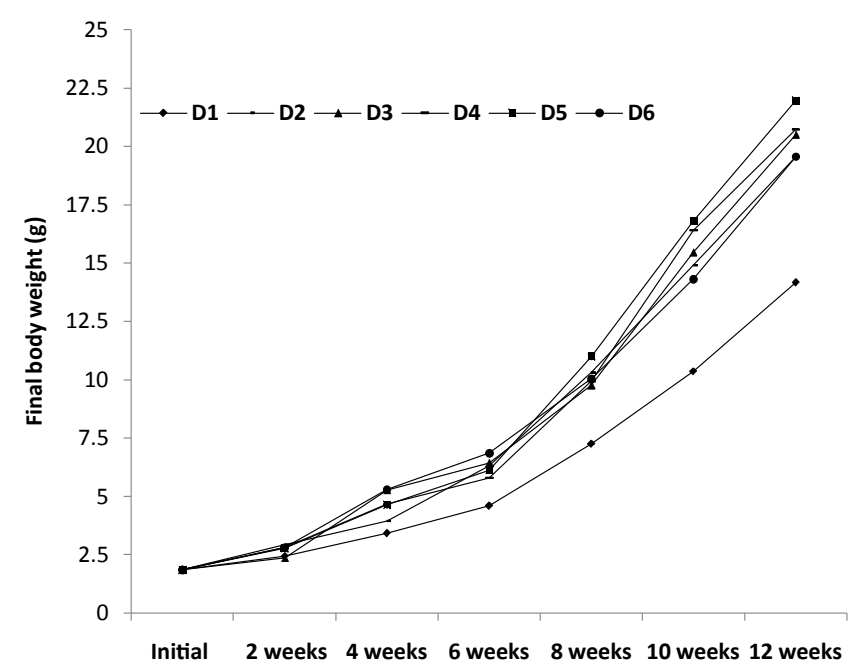

Figure 2: Final body weight of Nile tilapia fry fed diets containing $B$. licheniformis, fennel oil, garlic oiland their combinedfor 84 days. [D1= Control $\mathrm{D} 2$ = B. licheniformis; D3 = Essential fennel oil (EFO); D4 = Essential garlic oil $(\mathrm{EGO}) ; \mathrm{D} 5=(\mathrm{EFO}+\mathrm{B}$. licheniformis $) ; \mathrm{D} 6=(\mathrm{EGO}+\mathrm{B}$. licheniformis $)]$. recorded by fish of $\mathrm{D} 5(\mathrm{EFO}+B$. licheniformis $)$ and $\mathrm{D} 6(\mathrm{EGO}+B$. licheniformis). No significant differences were found in $\mathrm{Hct}, \mathrm{Hb}$ and RBCs among D1 (control diet), D2 (B. licheniformis), D3 (EFO) and D4 (EGO) treatments groups. Aspartate aminotransferase (AST) and alanine aminotransferase $(\mathrm{ALT})$ were significantly lower $(\mathrm{P}<0.05)$ in fish D5 $(\mathrm{EFO}+$ B. licheniformis $)$ and D6 $(\mathrm{EGO}+$ B. licheniformis $)$ in comparison to the other treatments, but, no significant differences were found in ALT and AST among D1 (control diet), D2 (B. licheniformis), D3 (fennel oil) and D4 (EGO) treatments groups. The results showed the serum total protein and serum globulin was significantly higher $(\mathrm{P}<0.05)$ in fish fed $\mathrm{D} 5(\mathrm{EFO}+B$. licheniformis $)$ and $\mathrm{D} 6(\mathrm{EGO}+B$ licheniformis). There was no significant $(\mathrm{P}>0.05)$ effect of different treated diets on serum albumin.

\section{Chemical composition}

Proximate analysis of whole body of O. niloticus fed the experimental diets was presented in Table 5 . The chemical composition of whole body appeared that no significant differences were found in dry matter and ash content of fish fed control and treated diets.

\section{Discussion}

The present study indicated that the highest growth and feed utilization were obtained at $1 \mathrm{ml}$ of EFO and EGO combined with $B$. licheniformis $7 \times 10^{7}\left(\mathrm{CFU} \mathrm{g}{ }^{-1}\right)$. This study of the application of EFO and EGO in diet showed the first report about the growth indices of Nile tilapia. Whereas, fennel seed as a powder was used as the growth

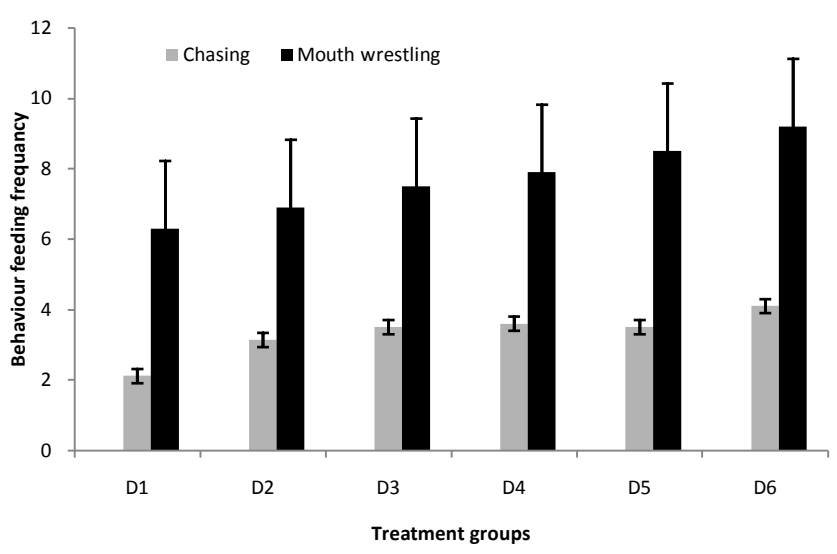

Figure 3: Behaviour feeding Final body weight of Nile tilapia fry fed diets containing $B$. licheniformis, fennel oil, garlic oiland their combinedfor 84 days. [D1= Control; D2 = B. licheniformis; D3 = Essential fennel oil (EFO); D4 = Essential garlic oil $(\mathrm{EGO}) ; \mathrm{D} 5=(\mathrm{EFO}+B$. licheniformis $) ; \mathrm{D} 6=(\mathrm{EGO}+B$ licheniformis)].

\begin{tabular}{|c|c|c|c|c|c|c|c|}
\hline \multirow[t]{2}{*}{ Parameters } & \multicolumn{6}{|c|}{ Experimental diets } & \multirow[t]{2}{*}{$P$ value } \\
\hline & D1 & D2 & D3 & D4 & D5 & D6 & \\
\hline Initial body weight (g) & $1.78 \pm 0.12$ & $1.90 \pm 0.16$ & $1.90 \pm 0.11$ & $1.92 \pm 0.09$ & $1.93 \pm 0.13$ & $1.82 \pm 0.14$ & 0.827 \\
\hline Weight gain (g) & $12.37 \pm 1.55^{c}$ & $17.66 \pm 1.23^{b}$ & $18.86 \pm 1.43^{b}$ & $18.80 \pm 1.52^{b}$ & $20.02 \pm 1.47^{a}$ & $19.58 \pm 1.61^{\mathrm{a}}$ & 0.010 \\
\hline Specific growth rate & $2.34 \pm 0.04^{c}$ & $2.59 \pm 0.10^{b}$ & $2.63 \pm 0.03^{b}$ & $2.64 \pm 0.43^{b}$ & $2.70 \pm 0.05^{a}$ & $2.70 \pm 0.062^{a}$ & 0.012 \\
\hline Feed intake ( $\mathrm{g}$ feed/ fish) & $20.69 \pm 1.21^{c}$ & $24.70 \pm 1.25^{b}$ & $24.64 \pm 1.11^{b}$ & $25.48 \pm 1.40^{\mathrm{a}}$ & $25.95 \pm 1.26^{a}$ & $25.09 \pm 1.32^{\mathrm{a}}$ & 0.001 \\
\hline Feed conversion ratio & $1.67 \pm 0.66^{a}$ & $1.42 \pm 0.68^{b}$ & $1.32 \pm 0.14^{c}$ & $1.36 \pm 0.14^{c}$ & $1.30 \pm 0.58^{c}$ & $1.28 \pm 0.66^{c}$ & 0.001 \\
\hline Protein efficiency ratio & $2.08 \pm 0.11^{c}$ & $2.38 \pm 0.18^{b}$ & $2.53 \pm 0.14^{a}$ & $2.47 \pm 0.17^{a}$ & $2.57 \pm 0.13^{a}$ & $2.60 \pm 0.21^{a}$ & 0.012 \\
\hline
\end{tabular}

Results are presented as means \pm SD of triplicate observations. Means in the same row with different superscripts were significantly different ( $<<0.05)$. D1= Control; D2 = B. licheniformis; D3 = Essential fennel oil (EFO); D4 = Essential garlic oil (EGO); D5 = (EFO + B. licheniformis); D6= (EGO + B. licheniformis).

Table 2: Fish performance and feed utilization of Nile tilapia fry fed diets containing $B$. licheniformis, essential oil of fennel and garlic and their combined for 84 days. 
Citation: Hassaan MS, Soltan MA (2016) Evaluation of Essential Oil of Fennel and Garlic Separately or Combined with Bacillus licheniformis on the Growth, Feeding Behaviour, Hemato-biochemical Indices of Oreochromis niloticus (L.) Fry. J Aquac Res Development. 7: 422. doi:10.4172/2155-9546.1000422

Page 5 of 8

\begin{tabular}{|c|c|c|c|c|c|c|c|}
\hline \multirow[t]{2}{*}{ Parameters } & \multicolumn{6}{|c|}{ Experimental diets } & \multirow[t]{2}{*}{$P$ value } \\
\hline & D1 & D2 & D3 & D4 & D5 & D6 & \\
\hline Hematocrit (\%) & $17.90 \pm 0.52^{\mathrm{b}}$ & $17.45 \pm 0.63^{\mathrm{b}}$ & $17.50 \pm 0.75^{\mathrm{b}}$ & $17.05 \pm 0.28^{\mathrm{b}}$ & $21.68 \pm 0.85^{a}$ & $23.00 \pm 0.74^{a}$ & 0.012 \\
\hline Hemoglobin (g/ dl) & $10.80 \pm 0.24^{b}$ & $10.90 \pm 0.23^{b}$ & $10.25 \pm 0.41^{\mathrm{b}}$ & $11.00 \pm .035^{\mathrm{b}}$ & $12.05 \pm 0.35^{a}$ & $13.80 \pm 0.25^{a}$ & 0.041 \\
\hline Red blood cells $\left(\times 10^{6} \mu \mathrm{L}^{-1}\right)$ & $1.93 \pm 0.02^{\mathrm{b}}$ & $1.91 \pm 0.01^{\mathrm{b}}$ & $2.12 \pm 0.05^{b}$ & $2.12 \pm 0.04^{b}$ & $2.82 \pm 0.02^{\mathrm{a}}$ & $2.78 \pm 0.06^{a}$ & 0.001 \\
\hline
\end{tabular}

Table 3: Hematological indices of Nile tilapia fry fed diets containing $B$. licheniformis, essential oil of fennel and garlic and their combined for 84 days.

\begin{tabular}{|c|c|c|c|c|c|c|c|}
\hline \multirow[t]{2}{*}{ Parameters } & \multicolumn{6}{|c|}{ Experimental diets } & \multirow[t]{2}{*}{$P$ value } \\
\hline & D1 & D2 & D3 & D4 & D5 & D6 & \\
\hline Aspertataminotransferase $\left(\mathrm{ul}^{-1}\right)$ & $11.80 \pm 0.47^{a}$ & $11.90 \pm 0.65^{a}$ & $10.95 \pm 0.68^{a}$ & $11.20 \pm 0.23^{a}$ & $9.15 \pm 0.39 b$ & $9.40 \pm 0.62^{b}$ & 0.014 \\
\hline Alanine aminotransferase $\left(\mathrm{ul}^{-1}\right)$ & $10.35 \pm 0.36^{a}$ & $10.05 \pm 0.45^{a}$ & $9.75 \pm 0.13^{a}$ & $9.90 \pm 0.75^{a}$ & $8.55 \pm 0.63^{b}$ & $8.25 \pm 0.58^{b}$ & 0.001 \\
\hline Total protein $\left(\mathrm{g} \mathrm{dL}^{-1}\right)$ & $2.70 \pm 0.12^{c}$ & $2.90 \pm 0.14^{c}$ & $3.00 \pm 0.16^{b}$ & $3.10 \pm 0.15^{\mathrm{b}}$ & $3.69 \pm 0.11^{\mathrm{a}}$ & $3.67 \pm 0.15^{\mathrm{a}}$ & 0.042 \\
\hline Albumin $\left(\mathrm{g} \mathrm{dL}^{-1}\right)$ & $0.95 \pm 0.02$ & $0.95 \pm 0.01$ & $0.99 \pm 0.01$ & $1.00 \pm 0.04$ & $1.05 \pm 0.01$ & $1.01 \pm 0.2$ & 0.562 \\
\hline Globulin $\left(\mathrm{g} \mathrm{dL}^{-1}\right)$ & $1.75 \pm 0.13^{c}$ & $1.95 \pm 0.17^{b}$ & $2.01 \pm 0.12^{b}$ & $2.10 \pm 0.13^{b}$ & $2.64 \pm 0.11^{\mathrm{a}}$ & $2.66 \pm 0.12^{\mathrm{a}}$ & 0.013 \\
\hline
\end{tabular}

Table 4: Biochemical blood indices of Nile tilapia fry fed diets containing $B$. licheniformis, essential oil of fennel and garlic and their combined for 84 days.

\begin{tabular}{|c|c|c|c|c|c|c|c|}
\hline \multirow[t]{2}{*}{ Parameters } & \multicolumn{6}{|c|}{ Experimental diets } & \multirow[t]{2}{*}{$P$ value } \\
\hline & D1 & D2 & D3 & D4 & D5 & D6 & \\
\hline Dry matter & $275.30 \pm 1.23$ & $277.20 \pm 1.45$ & $274.50 \pm 2.32$ & $275.01 \pm 1.54$ & $275.00 \pm 1.25$ & $278.52 \pm 1.58$ & 0.620 \\
\hline Crude protein & $149.20 \pm 1.23$ & $152.13 \pm 1.51$ & $151.20 \pm 1.45$ & $152.35 \pm 1.55$ & $153.89 \pm 1.63$ & $153.69 \pm 1.26$ & 0.452 \\
\hline Crude lipid & $64.23 \pm 1.10$ & $62.21 \pm 0.98$ & $61.13 \pm 1.24$ & $61.16 \pm 1.44$ & $60.73 \pm 1.28$ & $61.12 \pm 1.35$ & 0.521 \\
\hline Ash & $33.12 \pm 1.01$ & $33.99 \pm 1.20$ & $34.13 \pm 1.21$ & $33.12 \pm 1.00$ & $32.95 \pm 0.99$ & $32.80 \pm 1.01$ & 0.232 \\
\hline
\end{tabular}

Table 5: Chemical composition of Nile tilapia fry fed diets containing $B$. licheniformis, essential oil of fennel garlic and their combined for 84 days ( $\mathrm{g} / \mathrm{kg}$ wet basis).

promoter for Nile tilapia (O. niloticus) and the results are similar with the present study [14,33]. Besides, most of the authors have studied the effect of garlic as a powder form on growth and nutrient utilization $[17,26,34,35]$. The growth rates for the previous studies were significantly higher in fish fed diets supplemented with garlic than control groups. Garlic contains allicin, which promotes biogenic performance due to its positive effect on the intestinal flora, thereby improving digestion and enhancing nutrients utilization which influences the growth of fish [36]. Steam distillation of mashed garlic produces garlic oil containing methyl and allyl-sulphides of allicin and having the practical advantage of being more stable than allicin itself [37]. Due to the fact that the extracted essential oil from herbal plants has much higher contents of active substance than dried herbal plants resulting in the essential oil is usually used in low percentages in the diet compared to dried herbal plants.

Little information has been reported the effect of application of different essential oil in fish growth. These studies indicated that diets supplemented with essential oil of weet orange peel (Citrus sinensis) and Aloysia triphylla $([19,38]$ with different dose could enhance weight gain and specific growth rate. Supplementation of the essential oil of fennel or garlic in diet may improve digestibility, availability of nutrients and lead to a higher protein synthesis, which in turn could explain the better growth in this study. Meanwhile, stimulation of growth by $B$. licheniformis in the present study may attribute to improve digestibility by enhancing the synthesis of vitamins, enzymatic activity [39]. These results are in agreement with Bacillus subtilis [40]; carp [41], Tilapia O. nilotica.

On the other hand, the increase in growth for the combined application of EFO and/or EGO with B. licheniformis may be due to the
EFO and EGO promoted the growth of exogenous probionts bacteria $B$. licheniformis in gastrointestinal of fish more than other endogenous populations bacteria, which improved the growth performance of Nile tilapia. The control of the microflora in intestinal fish by addition of oregano essential oil (Origanum heracleoticum L) can positively effect on growth performance [18]. The main way of the essential oil work seems to be through the regulation of intestinal microflora [42]. From aforementioned, the essential oil of fennel and garlic are good potential alternatives to the growth promoters.

The feeding behaviour of fish is complex [43], however, the acceptance or rejection of diet is physiologically dependent on inputs from chemoreception [44]. Fish have several chemosensory systems including gustation (taste), olfaction (smell), chemical sensory and chemoreceptor cells. The role of herbal plants for feeding behaviour represented in the flavor, thereby influences of eating patterns, the secretion of digestive fluids and total feed intake [45]. It seems that fish fed EGO combined with $B$. licheniformis could be stimulated the gustatory system is the most important in acquisition and ingestion of food. Allicin has an intense garlic flavor with a strong effect on olfaction in the most aquatic animals such as Pelodiscus sinensis, Ctenopharyngodon idellus, Cyprinus carpio, Carassius auratus, and Oreochromis niloticus [45]. Harada [46] indicated that garlic had a strong food calling effecting on loach (Oriental weatherfish) and Japanese amberjack, Seriola quinqueradiata Temminck et Schlegel.

Hematological variables are good predictors for explaining the health status of fish [47]. The highest $\mathrm{Hct}, \mathrm{Hb}$ and RBCs count were obtained at D5 (EFO + B. licheniformis) and D6 (EGO + Bacillus licheniformis). Erythrocytes content in fish blood gives a guide to the health status of fish and can be helpful to determine any abnormalities 
Citation: Hassaan MS, Soltan MA (2016) Evaluation of Essential Oil of Fennel and Garlic Separately or Combined with Bacillus licheniformis on the Growth, Feeding Behaviour, Hemato-biochemical Indices of Oreochromis niloticus (L.) Fry. J Aquac Res Development. 7: 422. doi:10.4172/2155-9546.1000422

arising from the use of immunostimulants. Accordingly, the elevate number of RBCs multiplies the concentration of hemoglobin ultimately resulting in a high capacity for oxygen carrying which improved the health of fish and consequently enhancing growth [48]. Furthermore, Fazllolahzadeh et al. [37] assumed that the increase of blood indices such as, Hct, Hb, and RBCs may be attributable to a defense reaction against garlic which occurs by stimulation of erythropoiesis. The number of RBCs was significantly $(\mathrm{P}<0.05)$ higher in Asian sea bass, Lates calcarifer [49], Labeo rohita [50] and Nile tilapia, O. niloticus fed diet supplemented with garlic as a powder form. The present study is inconsistent with Soltan and El-Laithy [51]. They reported that fennel seeds and garlic powder did not effect on $\mathrm{Hct}$ and $\mathrm{Hb}$ values for Nile tilapia, O. niloticus. Yılmaz and Ergün [52] reported that garlic oil did not produce any undesired effects on hematological characteristics for Sea Bass Dicentrarchus labrax. With regard to the different essential oil addition Acar et al. [19] showed that O. mossambicus fed a basal diet containing $1 \%$ thyme, rosemary or fenugreek for 45 -day increased RBCs count and Hct value.

Alanine aminotransferase (ALT) and aspartate aminotransferase (AST) are liver enzymes and they have the function of transferring the amino group from alpha-amino acids to alpha-keto acids. A large amount of ALT and AST is released in the blood mostly during liver cell damage [53]. Thus, detection of the serum level of ALT and AST allows monitoring liver cell damage. The diets containing $(\mathrm{EFO}+B$. licheniformis) and (EGO + B. licheniformis) could decrease the activity of ALT and AST compared to other treatment groups. Similar results were obtained by El-Dakar [33] who showed a significant lower $(\mathrm{P}<0.05)$ in levels of ALT and AST in Nile tilapia, O. niloticus fed fennel seed meal supplemented with diet. Also, Soltan and El-Laithy [51] found that ALT and AST levels were significantly decreased when Nile tilapia fed diets supplemented with $1 \%$ garlic powder or $1 \%$ fennel seed with compared to other diets. Application of garlic (Allium sativum) may cause stabilization cell membrane and protect the liver against deleterious agents and free radical-mediated toxic. This is reflected in the reduction of liver enzymes [37]. Also, Metwally [54] indicated that garlic-addition helps the liver to maintain its normal function by accelerating the generative capacity of its cells. The different active components found in essential oil of fennel and garlic may play an important role in enhancing the activity of liver enzymes but the exact mechanism for this need more advanced study. Globulin fractions are certainly important for maintaining a healthy immune system and immune function in the blood [55]. The increase in total protein and globulin contents is thought to reflect strong innate immunity [17]. In this study, diets supplemented with $(\mathrm{EFO}+B$. licheniformis $)$ and $(\mathrm{EGO}+B$. licheniformis) showed a significant elevate in total protein and globulin in Nile tilapia. It can be inferred that the EFO and EGO which combined with $B$. licheniformis may enhance the non-specific immune response and more tolerant of stressful conditions of Nile tilapia. These results are similar with [20] who reported that the highest content of total protein was determined in fish fed diet supplemented with mixed oil of (thyme and fennel) with level $100 \mathrm{ml} \mathrm{kg}^{-1}$ diet, but serum albumin was not significantly different from the control group. The addition of garlic products, fresh oil and powdered forms increased the total protein in Nile tilapia O. niloticus, even at low level $0.25 \%$ of garlic oil [54]. Also, Shalaby et al. [16] reported that the highest total protein was determined in Nile tilapia O. niloticus when garlic powder was supplemented to the diet at $10 \mathrm{~g} \mathrm{~kg}^{-1}$ diet. Serum total protein and albumin contents decreased in sea bass exposed to garlic oil $(0.005$ $\mathrm{ml} \mathrm{L}^{-1}$ water) via bath immersion for $96 \mathrm{~h}$, but serum globulin was decreased at $\left(0.02 \mathrm{ml}_{\left.\text {of garlic oil } \mathrm{L}^{-1}\right)}\right.$ [52].
The present study indicated that no significant differences in chemical composition of body of fish fed different treated diets. In this regard, Abd El Hakim [14] found no significant differences in the chemical body composition of Nile tilapia fed diet supplemented with different level of fennel seed. Contrarily, Maniat et al. [56] showed that garlic supplemented in diets induce higher protein and lower fat content in body of benni fish (Mesopotamichthys sharpeyi). Ahmad and Abdel-Tawwab [13] reported that no significant differences $(\mathrm{P}>0.05)$ in moisture and crude protein in Nile tilapia, Oreochromis niloticus body meanwhile total lipids increased by increasing level of caraway seed (belonging to family Apiaceae as fennel). Shalaby et al. [16] reported the highest crude protein and the lowest crude lipid content were obtained by Nile tilapia fed diet supplemented with $30 \mathrm{~g} \mathrm{~kg}^{-1}$ garlic. Furthermore, Talpur and Ikhwanuddin [49] showed that sea bass fed diet supplemented with garlic was decreased in lipid content in body. Also, Metwally [54] showed that crude protein and ash was increased significantly in $O$. niloticus while crude lipid decreased significantly with diets containing different sources of Allium sativum.

In conclusion, addition of essential oil of fennel combined with $B$. licheniformis and/or essential oil of garlic combined with $B$. licheniformis resulting in increased growth performance and enhancement of hematological and biochemical blood parameters in Nile tilapia O. niloticus.

\section{Acknowledgements}

The authors are grateful to Animal production (Fish Nutrition Lab) staffs for thei help in data collection and analysis. We thank National Institute of Oceanography and Fisheries (NIOF), Egypt, for their help in hematological study. The authors confirm that there is no conflict of interest.

\section{References}

1. Rico A, Phu TM, Satapornvanit K, Min J, Shahabuddin AM, et al. (2013) Use of veterinary medicines, feed additives and probiotics in four major internationally traded aquaculture species farmed in Asia. Aquaculture 412: 231-243.

2. Reverter M, Bontemps N, Lecchini D, Banaigs B, Sasal P (2014) Use of plant extracts in fish aquaculture as an alternative to chemotherapy: current status and future perspectives. Aquaculture 433: 50-61.

3. Christaki E, Bonos E, Giannenas I, Florou-Paneri P (2012) Aromatic plants as a source of bioactive compounds. Agriculture 2: 228-243.

4. Kadri A, Zied Z, Ines BC, Ahmed B, Néji G, et al. (2011) Chemical constituents and antioxidant properties of Rosmarinus officinalis $L$. essential oil cultivated from South-Western Tunisia. J Med Plants Res 5: 5999-6004

5. Botsoglou N, Christaki E, Florou-Paneri P, Giannenas I, Papageorgiou G, et al (2004) The effect of a mixture of herbal essential oils or á-tocopheryl acetate on performance parameters and oxidation of body lipid in broilers. South African Journal of Animal Science 34: 52-61.

6. Platel K, Srinivasan K (2004) Digestive stimulant action of spices: A myth or reality? Indian Journal of Medical Research 119: 167-179.

7. Özbek H, Uğraş S, Dülger H, Bayram I, Tuncer I, et al. (2003) Hepatoprotective effect of Foeniculum vulgare essential oil. Fitoterapia 74: 317-319.

8. Choi EM, Hwang JK (2004) Antiinflammatory, analgesic and antioxidan activities of the fruit of Foeniculum vulgare. Fitoterapia 75: 557-565

9. Özcan, U, Yilmaz E, Ozcan L, Furuhashi M, Vaillancourt E, et al. (2006) Chemical chaperones reduce ER stress and restore glucose homeostasis in a mouse model of type 2 diabetes. Science 313: 1137-1140.

10. Lanzotti V (2006) The analysis of onion and garlic. Journal of Chromatography A 1112: 3-22.

11. Harris J, Cottrell SL, Plummer S, Lloyd D (2001) Antimicrobial properties of Allium sativum (garlic). Applied Microbiology and Biotechnology 57: 282-286.

12. Helou L, Harris IM (2007) Herbal products; toxicology and clinical pharmacology (2ndedn). Totowa, Human Press, New Jersey.

13. Ahmad MH, Abdel-Tawwab M (2011) The use of caraway seed meal as a feed 
Citation: Hassaan MS, Soltan MA (2016) Evaluation of Essential Oil of Fennel and Garlic Separately or Combined with Bacillus licheniformis on the Growth, Feeding Behaviour, Hemato-biochemical Indices of Oreochromis niloticus (L.) Fry. J Aquac Res Development. 7: 422. doi:10.4172/2155-9546.1000422

Page 7 of 8

additive in fish diets: Growth performance, feed utilization, and whole-body composition of Nile tilapia, Oreochromis niloticus (L.) fingerlings. Aquaculture 314: 110-114.

14. Abd El Hakim N (2010) Response of Nile tilapia, Oreochromis niloticus to diets supplemented with different levels of fennel seeds meal (Foeniculum vulgare). Abbassa International Journal of Aquaculture 3: 215-230

15. Yılmaz S, Ergün S, Soytaş N (2013) Dietary supplementation of cumin (Cuminum cyminum) preventing streptococcal disease during first-feeding of Mozambique tilapia (Oreochromis mossambicus). J Bio Sci Biotech 2: 117-124.

16. Shalaby A, Khattab Y, Abdel RA (2006) Effects of garlic (Allium sativum) and chloramphenicol on growth performance, physiological parameters and survival of Nile Tilapia (Oreochromis niloticus). J Venom Anim Toxins incl Trop Dis 12: 172-201.

17. Nya EJ, Austin B (2009) Use of garlic, Allium sativum, to control Aeromonas hydrophila infection in rainbow trout, Oncorhynchus mykiss (Walbaum). J Fish Dis 32: 963-970.

18. Zheng Z, Tan YWJ, Liu HY, Zhou XH, Xiang X, et al. (2009) Evaluation of oregano essential oil (Origanum heracleoticum L.) on growth, antioxidant effect and resistance against Aeromonas hydrophila in channel catfish (Ictalurus punctatus). Aquaculture 292: 214-218.

19. Acar Ü, Kesbic OS, Yilmaz S, Gultepe N, Turker A (20115) Evaluation of the effects of essential oil extracted from sweet orange peel (Citrus sinensis) on growth rate of tilapia (Oreochromis mossambicus) and possible disease resistance against Streptococcus iniae. Aquaculture 437: 282-286.

20. Gulec AK, Danabas D, Ural M, Seker E, Arsian A, et al. (2013) Effect of mixed use of thyme and fennel oils on biochemical properties and electrolytes in rainbow trout as a response to Yersinia ruckeri infection. Acta Veterinaria Brno 82: $297-302$

21. Greathead H (2003) Plants and plant extracts for improving animal productivity. Proc Nutr Soc 62: 279-290.

22. NRC (National Research Council) (1993) Nutrient requirements of fish Committee on Animal Nutrition. Board on Agriculture in National Research Council National Academy Press, Washington DC, USA

23. Boyd C (1979) Water quality in warm water fish ponds. Auburn University Agricultural Experiment Station. Auburn, AL.

24. Aazza S, Lyoussi B, Miguel MG (2011) Antioxidant and antiacetylcholinesterase activities of some commercial essential oils and their major compounds. Molecules 16: 7672-7690.

25. Douiri L, Boughdad A, Assobhei O, Moumni M (2013) Chemical composition and biological activity of Allium sativum essential oils against Callosobruchus maculatus. J Env Sci Toxicol Food Tech 3: 30-36.

26. Shelby RA, Lim C, Mediha Y, Mary AD (2006) Effects of probiotic diet supplements on disease resistance and immune response of young Nile tilapia, Oreochromis niloticus. Journal of Applied Aquaculture 18: 23-34.

27. Hussein EES, Konrad D, Deyab MSDE, Bong-Joo L (2013) Enhancing the growth of Nile tilapia larvae/juveniles by replacing plant (gluten) protein with algae protein. Aquaculture Research 44: 937-949.

28. AOAC (1995) Official Methods of Analysis of the Association Official Analytical Chemists (16thedn). AOAC International, Arlington, USA.

29. Reitman S, Frankel S (1957) A colorimetric method for the determination of serum glutamic oxalo-acetic and glutamic pyruvic transaminases. American journal of clinical pathology 28: 56-63

30. Doumas BT, Bayse DD, Carter RJ, Peters T, Schaffer R (1981) A candidate reference method for determination of total protein in serum. I. Development and validation. Clinical Chemistry 27: 1642-1650.

31. Duncan DB (1955) Multiple range and multiple F tests. Biometrics 11: 1-42.

32. Zar J (1984) Multiple comparisons. Biostatistical analysis 1: 185-205.

33. El-Dakar AY (2004) Use of medical and aromatic plants in fish diets: 2. Effect of dried basil leaves on performance of hybrid tilapia Oreochromis niloticus $\times$ O. aureus, Fingerlings., In: 3rd International Conference on Animal Production and Health in semi-Arid Areas, Suez Canal Univ.

34. Diab AS, Salah MA, George J, Yasser A, Mohamed FM (2008) Effect of garlic black seed and Biogen as immunostimulants on the growth and survival of Nile tilapia, Oreochromis niloticus (Teleostei: Cichlidae), and their response to artificial infection with Pseudomonas fluorescens. African Journal of Aquatic Science 33: 63-68

35. Amin F, Milad K, Mohammad S, Mohsen SI, Morteza D, et al. (2010) Effect of garlic (Allium sativum) on growth factors, some hematological parameters and body compositions in rainbow trout (Oncorhynchus mykiss) 3: 317-323.

36. Khalil R, Nadia B, Soliman M (2001) Effects of Biogen and Levamisol Hcl on the immune response of cultured Oreochromis niloticus to Aeromonas hydrophila vaccine. Beni-Suef Vet Med J Egypt 11: 381-392.

37. Fazllolahzadeh F, Keramati K, Saeed N, Shirian S, Samira S (2011) Effect of garlic (Allium sativum) on hematological parameters and plasma activities of ALT and AST of rainbow trout in temperature stress. Australian Journal of Basic and Applied Sciences 5: 84-90.

38. Zeppenfeld C, Hernández DR, Santinón JJ, Heinzmann BM, Schmidt D, et al. (2015) Essential oil of Aloysia triphylla as feed additive promotes growth of silver catfish (Rhamdia quelen). Aquaculture Nutrition.

39. Gatesoupe $\mathrm{F}$ (1999) The use of probiotics in aquaculture. Aquaculture 180 $147-165$

40. Zhang Q, Ma H, Mai K, Zhang W, Liufu Z, et al. (2010) Interaction of dietary Bacillus subtilis and fructooligosaccharide on the growth performance, nonspecific immunity of sea cucumber, Apostichopus japonicus. Fish Shellfish Immunol 29: 204-211.

41. Aly SM, Abdel-Galil Ahmed Y, Abdel-Aziz Ghareeb A, Mohamed MF (2008) Studies on Bacillus subtilis and Lactobacillus acidophilus, as potential probiotics on the immune response and resistance of Tilapia nilotica (Oreochromis niloticus) to challenge infections. Fish Shellfish Immunol 25: 128-136.

42. Hernández A, Benjamin GG, Maria JC, Maria DH (2015) The inclusion of thyme essential oil in the feed of gilthead seabream (Sparus aurata) promotes changes in the frequency of lymphocyte aggregates in gut-associated lymphoid tissue. Aquaculture Research.

43. Houlihan D, Boujard T, Jobling M (2008) Food intake in fish, John Wiley and Sons.

44. Hara T (1994) Olfaction and gustation in fish: an overview. Acta Physiol Scand 152: $207-217$.

45. Lee JY, Gao Y (2012) Review of the application of garlic, Allium sativum, in aquaculture. Journal of the World Aquaculture Society 43: 447-458.

46. Harada K (1990) Attraction activities of spices for oriental weather fish and yellowtail. Nippon Suisan Gakkaishi 56: 2029-2033.

47. Hrubec TC, Cardinale JL, Smith SA (2000) Hematology and plasma chemistry reference intervals for cultured tilapia (Oreochromis hybrid). Vet Clin Pathol 29: 7-12.

48. Hassaan M, Soltan M, Ghonemy M (2014) Effect of synbiotics between Bacillus licheniformis and yeast extract on growth, hematological and biochemical indices of the Nile tilapia (Oreochromis niloticus). The Egyptian Journal of Aquatic Research 40: 199-208.

49. Talpur AD, Ikhwanuddin M (2012) Dietary effects of garlic (Allium sativum) on haemato-immunological parameters, survival, growth, and disease resistance against Vibrio harveyi infection in Asian sea bass, Lates calcarifer (Bloch) Aquaculture 364: 6-12.

50. Sahu S, Das BK, Mishra BK, Pradhan J, Sarangi N (2007) Effect of Allium sativum on the immunity and survival of Labeo rohita infected with Aeromonas hydrophila. Journal of Applied Ichthyology 23: 80-86.

51. Soltan MA, El-Laithy S (2008) Effect of probiotics and some spices as feed additives on the performance and behaviour of the Nile tilapia, Oreochromis niloticus. J Aquat Biol Fish 12: 63-80.

52. Yılmaz S, Ergün S (2012) Effects of garlic and ginger oils on hematological and biochemical variables of Sea Bass Dicentrarchus labrax. J Aquat Anim Health 24: $219-224$

53. Hassaan MS, Goda AM, Soaad AM, Tayel SI (2014) Protective effect of dietary vitamin $\mathrm{E}$ against fungicide copperoxychloride stress on Nile tilapia Oreochromis niloticus (L.), Fingerlings.

54. Metwally M (2009) Effects of garlic (Allium sativum) on some antioxidan activities in tilapia nilotica (Oreochromis niloticus). World Journal of Fish and Marine Sciences 1: 56-64. 
Citation: Hassaan MS, Soltan MA (2016) Evaluation of Essential Oil of Fennel and Garlic Separately or Combined with Bacillus licheniformis on the Growth, Feeding Behaviour, Hemato-biochemical Indices of Oreochromis niloticus (L.) Fry. J Aquac Res Development. 7: 422. doi:10.4172/2155-9546.1000422

Page 8 of 8

55. Jha AK, Pal AK, Sahu NP, Kumar S, Mukherjee SC et al. (2007) Haematoimmunological responses to dietary yeast RNA, Omega-3 fatty acid and $\beta$-carotene in Catla catla juveniles. Fish Shellfish Immunol 23: 917-927.
56. Maniat M, Ghotbeddin N, Ghatrami ER (2014) Effect of garlic on growth performance and body composition of benni fish (Mesopotamichthys sharpeyi). International Journal of Biosciences (IJB) 5: 269-277. 